\title{
GENÇLİK VE SPOR GENEL MÜDÜRLÜĞÜ FEDERASYONLARINDA GÖREV YAPAN PERSONELİN SPONSORLUKLA İLGILİ GÖRÜŞLERİ
}

\author{
Gülcan ŞAHİN ${ }^{1} \quad$ Oğuz ÖZBEK ${ }^{1}$
}

Geliş Tarihi: 23.08.2007

Kabul Tarihi: 04.02.2008

\begin{abstract}
ÖZET
Araştırmanın amacı Gençlik ve Spor Genel Müdürlüğü'ne bağlı spor federasyonlarında görev yapan personelin eğitim düzeyi, görev durumu ve hizmet süresine göre sponsorlukla ilgili görüşlerini saptamak ve araştırma sonuçlarına dayalı olarak önerilerde bulunmaktır. Araştırma tarama modelindedir. Konu ile ilgili bilgiler, kaynakların taranması ve geliştirilen ölçme aracının uygulanmasından elde edilmiştir. Araştırmanın evreni 153, örneklemi ise 127 kişiden oluşmuştur. Veriler frekans, yüzdelik ve aritmetik ortalama ile çözümlenmiştir. Spor federasyonlarında çalışan personelin, hizmet süresine göre görüşlerine ilişkin veriler ilişkisiz $t$ testi ile, görev ve öğrenim durumuna göre görüşlerine ilişkin veriler ise, tek yönlü varyans analizi ile test edilmiştir. Tek yönlü varyans analizi sonucunda anlamlı bulunan farklıı̆ı̆ kaynağını belirlemek için LSD testi uygulanmıştır.

Federasyonlarda görev yapan personel, sponsorluk yönetmeliğine dayanılarak belirlenen ifadelere orta düzeyde katıldığını belirtmiştir. Lise mezunu personel, önlisans-lisans ve lisansüstü mezunu personele göre, yaygın olmayan spor branşlarında daha az sponsorluk teklifi yapıldığını düşünmektedir. Kıdemi on yıldan az olan personel, daha kıdemli personele göre, sponsor kuruluşun kamuoyundaki imajının olumlu olmasının ve ürünlerinin insan sağlığına yararlı olmasının teklifinin kabul edilmesinde daha çok etkili olduğunu düşünmektedir.
\end{abstract}

Anahtar Kelimeler: Sponsorluk, Spor Federasyonu, Sponsorluk Yönetmeliği.

\section{THE SPONSORSHIP RELATED OPINIONS OF THE PERSONNEL EMPLOYED AT THE YOUTH AND SPORTS GENERAL DIRECTORATE FEDERATIONS}

\begin{abstract}
The objective is to determine the sponsorship related opinions of the personnel employed in the sports operations under the Youth and Sports General Directorate, depending on their education levels, positions, and service durations, and to make recommendations based on the outcomes of the research. The study was carried out scanning. The information about the subject was obtained by scanning the resources and the implementation of the developed measurement device. The universe of the research consists of 153 people, and the sample, of 127 people. The data has been analysed using percentage and arithmetic means. The data regarding the opinions of the personnel employed at the sports federations, depending on their service periods were tested using the $t$ test; and the data based on the position and the education were tested using a single directional variant analysis. In order to determine the reason for the difference as a result of the single direction variant analysis, an LSD test was applied.

The personnel employed at the federations had indicated that they agree at a medium level with the expressions made based on the sponsorship regulations. Upon comparison with the undergraduate, graduate personnel, the highscool graduates believe that there are less sponsorship offers in sports branches that are not common. Personnel with less than a decade in the organise thinks, in comparison with the more senior ones, that a positive public image and the products being beneficial for human health would be more effective in accepting the offer.
\end{abstract}

Key Words: Sponsorship, Sports Federation, Sponsorship Regulations

\section{GíRiş}

Sponsor, bir bireyi organizasyonu, olayı ya da faaliyeti desteklemek için aynî ya da nakdî yardım yapan kişi ya da kurumdur. Sponsor olan ve sponsor olunan taraflar arasındaki ilişki, karşılıklı kabul edilmiş ticari faydaları sağlayan bir ilişkidir (1). Büyük Larousse Ansiklopedisine göre sponsor, bir gösterinin, sportif kültürel bir yarışmanın giderlerinin bir

\footnotetext{
${ }^{1}$ Ankara Üniversitesi Beden Eğitimi ve Spor Yüksekokulu
} 
bölümümü, adının o gösteri ya da yarışma sırasında anııması karşılığında kabul eden özel ya da kamu kişi ya da kuruluş olarak tanımlanmaktadır (2). Sponsor sözcüğü İngilizce'de, kefil olmak, desteklemek, himaye etmek anlamına gelmektedir (3). İngiltere Spor Konseyi sponsorluğu; destekleyiciye tanıtım için öncelik veya ayrıcalık sağlayan ödemeler olarak tanımlamıştır (4). "Sponsorluğun psikolojik ve ekonomik hedefleri vardır. Ancak psikolojik hedefler genellikle ön plandadır" (5).

Günümüzde yeterli ekonomik destek sağlanmadığı takdirde, herhangi bir spor organizasyonunun düzenlenmesi zor olmaya başlamıştır. Ürünlerini büyük kitlelere kısa zamanda tanıtmak isteyen kuruluşlar, büyük kitlelere hitap edebilmesi nedeniyle spor sponsorluğunu tercih etmektedirler. Spor organizasyonlarının ekonomik destek intiyacı ile şirketlerin pazarlama ve reklam intiyacı spor sponsorluğuna olan talebi artırmıştır (6). "Sponsorluk pazarı gittikçe büyümektedir. Şirket evlilikleri arttıkça, şirketler kendilerine reklâmlarını yapabilecekleri alanlar aramaktadır” (7). Spor sponsorluğu, şirketin imajını olumlu etkilediği, markanın güvenirliğini artırdığı ve tüketicinin yaşamında olumlu bir izlenim yarattığı için yararlı bir yatırımdır (8).

Spor sponsorluğu, bireysel sporcu sponsorluğu, spor takımları sponsorluğu ve spor organizasyonları sponsorluğu olmak üzere üç şekilde yapılabilmektedir. Sponsorluk olmadan büyük organizasyonların gerçekleşmesi mümkün görünmemektedir. Olimpiyat oyunlarının \%100'ü, motor sporu yarışmalarının \%100'ü, golf turnuvalarının \%90'ı, tenis ve binicilik turnuvalarının \%50'si, futbol turnuvalarının \%20'sinin sponsorlar olmadan gerçekleştirilemeyeceği tahmin edilmektedir (6). Sponsorluk faaliyeti sonunda çeşitli yararlar ortaya çıkar. Sponsor olan işletmenin satışları artar, kimlik yaratır ve diğer işletmelerle olan ilişkileri artar. Sponsorluk sayesinde otomobil yarışları, tenis, binicilik ve olimpiyat oyunları gibi sporlar, milyonlarca kişiye ulaşır ve halka açık bir duruma gelir (9). Sponsorluk sporcuyu teşvik eder, motivasyonunu artırarak başarıya ulaşmasına katkıda bulunur, aynı zamanda iyi bir gelir elde etmesini sağlar.

Türkiye'de spor sponsorluğu yeni bir olgu olmasına rağmen birçok firma spora sponsor olmuştur. A Milli Futbol Takımımızın sponsor sayısı, 2002 Dünya Kupası öncesinde dörtten sekize yükselmiştir (Adidas, Pepsi, Sarar, Mercedes, Efes Pilsen, İş Bankası, Shell ve Turkcell). Türkiye Futbol Federasyonu bu sponsorluklardan 2005-2006 yılda 11.148.416 YTL. gelir elde etmiştir. Sportsmarketing Surveys tarafından yapılan bir araştırmada ise, 2002 yılında tüm dünyada yapılan sponsorluk türleri arasında spor sponsorluğunun ilk sırada geldiği görülmektedir (10). Spora ayrılan devlet harcamalarının kısıtlı olması sporun gelişmesini engellemekte, spor faaliyetlerini güçleştirmektedir. Sponsorluk anlaşmalarının artması halinde sponsorluk gelirleri devlet yardımının yerini alabilecek düzeye gelebilir (11).

Ülkemizde, Gençlik ve Spor Genel Müdürlüğü’ne (GSGM) bağlı 58 spor federasyonu bulunmaktadır. Bu federasyonların tamamı özerk yapıya kavuşmuştur. Gençlik ve Spor Genel Müdürlüğü Özerk Federasyon Spor Federasyonları Çerçeve Yönetmeliğine göre, özerk federasyon gelirleri arasında sponsorluk gelirleri de yer almaktadır. Sponsorluk yolu ile elde edilecek gelirler özerk federasyon bütçeleri için önem kazanmıştır. Spor federasyonları, ülkemizdeki ekonomik sıkıntılara bağıı olarak malî sıkıntı yaşamaktadır.

Erturan ve Yenel'in (12) yaptığı bir araştırmaya göre, federasyon başkanları, GSGM'nin federasyona ayırdığı bütçeyi az bulurken, malî kaynak oluşturmak için sponsorlukta, aynî nakdî yardımdan az yararlandıklarını belirtmişlerdir. Yine aynı araştırmada, federasyon başkanları, malî özerkliğin getirilmesi ile federasyonların bugünkünden daha fazla geliri, daha etkin ve verimli kullanacağına inanmaktadırlar.

GSGM Sponsorluk Şubesi verilerine göre, 2004-2007 yılları arasında, 27.987.308,96 YTL nakdî, 16.220.358,64 YTL değerinde ise aynî olmak üzere toplam 44.207.667,60 YTL sponsorluk anlaşması yapılmıştır. Bu miktarın dağılımına baktığımızda, kulüpler \%61'ini, federasyonlar \%15'ini, sporcular \%12'sini, diğer kurumlar \%6'sını, il müdürlükleri \%3'ünü ve daire başkanlıkları \%3'ünü elde etmiştir (13). Spor federasyonlarının sponsorluk anlaşmalarından elde ettiği gelir kulüplerin çok gerisinde kalmıştır. Federasyonların, ilgili olduğu branşın yaygınlaştırıması, altyapı çalışmalarında bulunması, ulusal ve uluslararası organizasyonları düzenlemesi gibi görevlerini yerine getirebilmesi için sponsorluk pastasından daha çok pay alması gerekmektedir.

Federasyonlar sponsorluk çalışmalarını, 16.06.2004 tarihli ve 25494 sayılı Resmi Gazete'de (14) yayımlanarak yürürlüğe giren Gençlik ve Spor Genel Müdürlüğü Sponsorluk Yönetmeliği'ne göre yürütmektedirler. Gençlik ve Spor Genel Müdürlüğü Sponsorluk Yönetmeliği'nde sponsorluk yapılabilecek alanlar, gençlik ve spor tesislerinin sponsorluk esasları, sözleşme yapılması ve sözleşmede yer alacak hususlar, sponsora verilebilecek haklar ve sponsorluk alımında uyulacak hususlar gibi başlıklar yer almaktadır. Bu yönetmeliğin federasyon personeli tarafından anlaşıması, benimsenmesi sponsorluk gelirlerini doğrudan etkileyecektir. Sponsorluk yönetmeliğine ilişkin federasyon personelinin görüşleri, sponsorluk uygulaması açısından önemlidir.

Bu araştırmanın genel amacı GSGM'ye bağlı spor federasyonlarında görev yapan personelin eğitim düzeyi, görev durumu ve hizmet süresine göre sponsorlukla ilgili görüşleri arasında anlamlı bir fark olup olmadığını saptamak ve araştırma sonuçlarına dayalı olarak önerilerde bulunmaktır.

\section{MATERYAL VE YÖNTEM}

Araştırma tarama modelindedir. Konu ile ilgili bilgiler, kaynakların taranması ve geliştirilen ölçme aracının uygulanmasından elde edilmiştir. Araştırmanın evreni GSGM'de ve bağlı federasyonlarda görev yapan genel sekreter, spor uzmanı ve memurlardan oluşmaktadır. Araştırmanın yapıldığı mayıs 2006 tarihinde, GSGM'ye bağlı 
federasyonlarda, 53 federasyon genel sekreteri, 40 spor uzmanı ve 60 memur olmak üzere 153 kişi görev yapmaktadır. Ural ve Kılıç'a (15) göre 160 kişilik evrenden alınacak örneklem sayısının alt sınırı, 0.05 tolerans gösterilebilir hata için 113 olarak saptanmıştır. Ölçme aracı 127 personele uygulanmıştır.

\section{Veri Toplama Aracı}

Ölçme aracı, GSGM Sponsorluk Yönetmeliği'nde (14), yer alan maddeler temel alınarak geliştirilmiştir. Ölçme aracının taslağında, kişisel bilgilerle ilgili 6 ve sponsorlukla ilgili 21 madde yer almıştır. Ölçek, beşli likert tipinde hazırlanmıştır. Ölçeğin seçenekleri ve bunların puanları, Hiç katılmıyorum (1 puan), Az katılıyorum (2 puan), Katılıyorum (3 puan), Çok katılıyorum (4 puan), Tam katılıyorum (5 puan) olarak belirlenmiştir. Beşli derecelendirme ölçeğindeki aralık için $(5-1=4)$, hesaplanan aralık katsayısına göre $(4 / 5=0.80)$ seçenek aralıkları, Hiç katılmıyorum (1.00-1.79), Az katılıyorum (1.80-2.59), Katılıyorum (2.60-3.39), Çok katılıyorum (3.40-4.19), Tam katılıyorum (4.20-5.00) olarak düzenlenmiştir.

Ölçme aracının, geçerlik ve güvenirlik çalışması bu araştırma kapsamında yapılmıştır. Güvenirlik için alfa katsayısına bakılmıştır. Ölçme aracının yapı geçerliği için iki ayrı madde analizi ve faktör analizi yapıımıştır. Ölçeğin yapı geçerliğini sağlamak için alt ve üst grup ortalamaları arasındaki farka dayalı madde analizine ve madde-toplam korelasyon değerlerine bakılmıştır (Tablo 1). Alt ve üst grup ortalamaları arasındaki farka dayalı madde analizi sonucunda elde edilen $t$ değerlerine bakılarak, bütün maddelerin ayırt etme gücüne sahip olduğu görülmüştür. Madde toplam korelasyonu değerinin en az .20 olması istenir (16). Bu durumda yalnız 1 madde değeri .20'nin altında kaldığı için ölçekten çıkarılmıştır .

Faktör analizi yapılmadan önce, verilerin faktör analizine uygunluğu için (Kaiser-Meyer-Olkin) KMO değerine bakılmış ve bu değer 7.68 bulunmuştur. Veriler üzerinde faktör analizi yapılabilmesi için minimum KMO değeri .60 olmalıdır (17). Bu durumda gözlenen .68'lik KMO değeri verilerin faktör analizi için uygun olduğunu göstermektedir. Diğer yandan 21 maddenin faktör analizi için Barlett testi sonucu [601.011 ( $p<0.001)$ ] olarak bulunmuştur. KMO ve Barlett testi sonuçları bu veriler üzerinde faktör analizi yapılabileceğini ortaya koymuştur. Faktör analizi tek boyut üzerinde yapılmıştır. Açıklanan toplam varyans \%30.2 bulunmuştur. Tek faktörlü ölçeklerde açıklanan varyansın \%30 ve daha yukarı olması yeterli görülmektedir (18). Herhangi bir maddenin ölçekte yer almasına karar verilirken faktör yük değerinin .30 ve daha yukarı olması ölçüt alınmıştır. Buna göre ölçekten 8 madde atılmıştır. Geriye kalan 13 maddenin yük değeri ise .35 ile .75 arasında değişmektedir (Tablo 1). Ölçeğin güvenirliği için hesaplanan Alpha iç tutarlılık katsayısı .78 olarak bulunmuştur. Bu durumda ölçeğin geçerli ve güvenilir olduğu kabul edilmiştir.

\section{Verilerin çözümlenmesi}

Veriler frekans ve yüzdelik ve aritmetik ortalama ile çözümlenmiştir. Spor federasyonlarında çalışan personelin, hizmet süresine göre görüşlerine ilişkin veriler ilişkisiz t testi ile, görev ve öğrenim durumuna göre ilişkin veriler ise, tek yönlü varyans analizi ile test edilmiştir. Tek yönlü varyans analizi sonucunda anlamlı bulunan farklılığın kaynağını belirlemek için LSD testi uygulanmıştır.

Tablo 1. Veri Toplama Aracının Faktör Analizi ve Madde Analizi Sonuçları ile t Değerleri

\begin{tabular}{|c|c|c|c|}
\hline Maddeler & $\begin{array}{l}\text { Faktör } \\
\text { yükü }\end{array}$ & \begin{tabular}{|c|} 
Alt-üst \\
ortalamalar \\
arası farkın \\
t-değeri (t)
\end{tabular} & $\begin{array}{c}\text { Madde- } \\
\text { toplam } \\
\text { korelasyon } \\
\text { katsayısı (r) }\end{array}$ \\
\hline 1. Sponsor firmalar doğrudan federasyona gelerek anlaşma yapmalıdır. & .44 & $40.39^{*}$ & .34 \\
\hline 2. Sponsorluk yapacak kuruluşun kamuoyunda tanınmış olması teklifin kabulünde etkilidir. & .71 & $26.72^{*}$ & .53 \\
\hline $\begin{array}{l}\text { 3. Sponsorluk yapacak kuruluşun kamuoyunda olumlu imajının bulunması teklifin kabulünde } \\
\text { etkilidir. }\end{array}$ & .69 & $19.74^{*}$ & .46 \\
\hline $\begin{array}{l}\text { 4. Sponsorluk yapacak kuruluşun ürünlerinin insan sağlığına yararlı olması teklifin kabulünde } \\
\text { etkilidir. }\end{array}$ & 69 & $20.24^{*}$ & .49 \\
\hline 5. Sponsorluk teklifinin kabul edilmesinde teklifin miktarı etkilidir. & .75 & 19.99* & .53 \\
\hline 6. Yaygın olmayan spor branşlarında daha az sponsorluk teklifi yapılmaktadır. & .52 & $18.67^{*}$ & .37 \\
\hline $\begin{array}{l}\text { 7. Takım sporunun ağırlıkta olduğu branşlarda ilgili federasyonlara daha çok sponsorluk teklifi } \\
\text { yapıımaktadır. }\end{array}$ & .49 & $23.93^{*}$ & .39 \\
\hline 8. Sponsorlar daha çok ulusal spor organizasyonlarını üstlenmelidir. & .40 & $25.60^{*}$ & .40 \\
\hline 9. Sponsorlar daha çok uluslararası spor organizasyonlarını üstlenmelidir. & .37 & $23.40^{*}$ & .35 \\
\hline 10.Sponsorlar yerel yönetimlere ait spor tesislerinin bakımını, onarımını ve yapımını üstlenmelidir. & .35 & $18.53^{*}$ & .28 \\
\hline 11.Sponsorlar ulusal ve uluslararası gençlik ve spor organizasyonlarını üstlenmelidir. & .45 & $22.42^{*}$ & .31 \\
\hline 12.Sponsorlar daha çok nakdî ödeme yapmalıdır. & .56 & $22.18^{*}$ & .41 \\
\hline 13.Sponsorlar okul sporlarını desteklemeye daha çok önem vermelidir. & .46 & $22.61^{*}$ & .35 \\
\hline
\end{tabular}

${ }^{*} \mathrm{p}<0.01$ 


\section{BULGULAR}

Araştırmaya katılan toplam 127 personelin 38'i kadın (\%30), 89'u erkek'tir (\%70). Araştırma grubunun 37'si lise $(\% 29,8), 71$ 'i ön lisans ve lisans (\%56,5), 17'si lisansüstü $(\% 13,7)$ eğitime sahiptir. Yaptıkları görevler bakımından 25 'i federasyon genel sekreteri (\%19,7), 41'i spor uzmanı (\%32,3), 61'i memur'dur (\%48). 43 kişi 26-32 yaş (\%34.1), 34 kişi 33-41 yaş $(\% 26,2)$ ve 50 kişi de 42 ve üstü yaş $(\% 39,7)$ grubundadır.

Tablo 2- Federasyonlarda Görev Yapan Personelin Sponsorlukla İlgili Görüşleri

\begin{tabular}{|c|c|c|c|c|c|c|c|c|c|c|c|}
\hline \multirow{3}{*}{$\begin{array}{c}\text { Tablo } \\
\text { 1'deki } \\
\text { Maddeler }\end{array}$} & \multicolumn{10}{|c|}{ Yanıt Seçenekleri } & \multirow{3}{*}{$\bar{x}$} \\
\hline & \multicolumn{2}{|c|}{$\begin{array}{c}\text { (1) Hiç } \\
\text { katılmıyorum }\end{array}$} & \multicolumn{2}{|c|}{$\begin{array}{c}\text { (2) } \mathrm{Az} \\
\text { katılıyorum }\end{array}$} & \multicolumn{2}{|c|}{$\begin{array}{c}(3) \\
\text { Katılıyorum }\end{array}$} & \multicolumn{2}{|c|}{$\begin{array}{c}\text { (4) Çok } \\
\text { katılıyorum }\end{array}$} & \multicolumn{2}{|c|}{$\begin{array}{l}(5) \text { Tam } \\
\text { katılıyorum }\end{array}$} & \\
\hline & $f$ & $\%$ & $\mathrm{f}$ & $\%$ & $f$ & $\%$ & $\mathrm{f}$ & $\%$ & $f$ & $\%$ & \\
\hline 1 & 15 & 12.0 & 25 & 20.0 & 33 & 26.4 & 16 & 12.8 & 36 & 28.8 & 3.26 \\
\hline 2 & 15 & 12.0 & 21 & 16.8 & 43 & 34.4 & 22 & 17.6 & 24 & 19.2 & 3.15 \\
\hline 3 & 11 & 8.8 & 16 & 12.8 & 47 & 37.6 & 24 & 19.2 & 27 & 21.6 & 3.32 \\
\hline 4 & 11 & 8.7 & 10 & 7.9 & 40 & 31.7 & 28 & 22.2 & 37 & 29.4 & 3.55 \\
\hline 5 & 8 & 6.3 & 17 & 13.5 & 43 & 34.1 & 28 & 22.2 & 30 & 23.8 & 3.43 \\
\hline 6 & 9 & 7.2 & 7 & 5.6 & 31 & 24.8 & 23 & 18.4 & 55 & 44.0 & 3.86 \\
\hline 7 & 5 & 4.0 & 22 & 17.5 & 40 & 31.7 & 27 & 21.4 & 32 & 24.5 & 3.46 \\
\hline 8 & 22 & 17.3 & 28 & 22.0 & 39 & 30.7 & 25 & 19.7 & 13 & 10.2 & 2.83 \\
\hline 9 & 20 & 16.1 & 23 & 18.5 & 45 & 36.3 & 20 & 16.1 & 16 & 12.9 & 2.91 \\
\hline 10 & 30 & 23.6 & 30 & 23.6 & 42 & 33.1 & 11 & 8.7 & 14 & 11.0 & 2.59 \\
\hline 11 & 6 & 4.8 & 15 & 12.0 & 40 & 32.0 & 22 & 17.6 & 42 & 33.6 & 3.63 \\
\hline 12 & 6 & 4.7 & 16 & 12.6 & 47 & 37.0 & 22 & 17.3 & 36 & 28.3 & 3.51 \\
\hline 13 & 5 & 3.9 & 15 & 11.8 & 40 & 31.5 & 20 & 15.7 & 47 & 37.0 & 3.70 \\
\hline
\end{tabular}

Tablo 2'ye göre, bütün maddeler arasında 6. madde olan "yaygın olmayan spor branşlarında daha az sponsorluk teklifi yapılmaktadır" maddesine katılma oranı en düşük düzeyde, 10. madde olan "sponsorlar yerel yönetimlere ait spor tesislerinin bakımını, onarımını ve yapımını üstlenmelidir" maddesine katılma oranı en yüksek düzeyde gerçekleşmiştir. 6. maddeye \%44'ü tam katılmakta, \% 5.6'sı ise az katılmaktadırlar (bu maddeye ilişkin görüşlerin ortalaması $\bar{x}=3.86$ 'dır). 10. maddeye \%33.1'i katılmakta, \%8.7'si ise çok katılmaktadırlar (bu maddeye ilişkin görüşlerin ortalaması $\bar{x}=2.59$ 'dur). Bütün maddelere katılma düzeylerinin genel ortalaması $(\Sigma \bar{x}=3.32)$ orta düzeyde gerçekleşmiştir. Federasyonlarda görev yapan personel, sponsorluk yönetmeliğine dayanılarak belirlenen ifadelere orta düzeyde katılmaktadırlar.

Federasyonlarda görev yapan personelin hizmet sürelerine göre, sponsorlukla ilgili maddelere ilişkin belirttiği görüşler arasında yapılan t testi sonuçlarına göre, Tablo 3’te görüldüğü gibi üç maddede istatistiki olarak anlamlı bir fark bulunmuştur.

Tablo 3'e göre, "sponsorluk yapacak kuruluşun kamuoyunda olumlu imajının bulunması teklifin kabulünde etkilidir" görüşüne hizmet süresi 1-10 yıl arasında olan personelin katılma düzeyleri $(\bar{x}=3,56)$ ile hizmet süresi 11 yıl ve daha fazla olan personelin katılma düzeyleri $(\bar{x}=3,08)$, arasında anlamlı bir fark vardır [t $(126)=.28, p<.05]$. Kıdemi 10 yıldan az olan personel, daha kıdemli personele göre, sponsor kuruluşun kamuoyundaki imajının olumlu olması teklifinin kabul edilmesinde daha çok etkili olduğunu düşünmektedir.

"Sponsorluk yapacak kuruluşun ürünlerinin insan sağlığına yararlı olması teklifin kabulünde etkilidir" görüşüne hizmet süresi 1-10 yıl arasında olan personelin katılma düzeyleri $(\bar{x}=3,78)$ ile hizmet süresi 11 yıl ve daha fazla olan personelin katılma düzeyleri ( $\bar{x}=3,33)$, arasında anlamlı bir fark vardır [t $(126)=.041, p<.05$ ]. Kıdemi 10 yıldan az olan personel, daha kıdemli personele göre, sponsor kuruluşun ürünlerinin insan sağlığına yararlı olması teklifinin kabulünde daha çok etkili olduğunu etkili olduğunu düşünmektedir.

"Yaygın olmayan spor branşlarında daha az sponsorluk teklifi yapılmaktadır" görüşüne hizmet süresi 1-10 yıl arasında olan personelin katılma düzeyleri $(\bar{x}=4,16)$ görüşü ile hizmet süresi 11 yıl ve daha fazla olan personelin katılma düzeyleri $(\bar{x}=3,60)$, arasında anlamlı bir fark vardır [t $(126)=.011, p<.05]$. Kıdemi 10 yıldan az olan personel, daha kıdemli personele göre, yaygın olmayan spor branşlarında daha az sponsorluk teklifi yapıldığını düşünmektedir.

"Sponsorlar okul sporlarını desteklemeye daha çok önem vermelidir" görüşüne hizmet süresi 1-10 yıl arasında olan personelin katılma düzeyleri $(\bar{x}=3,82)$ ile hizmet süresi 11 yıl ve daha fazla olan personelin katılma düzeyleri $(\bar{x}$ $=3,27$ ), arasında anlamlı bir fark vardır [t $(126)=.008, p<.05]$. Kıdemi 10 yıldan az olan personel, daha kıdemli personele göre, sponsorların okul sporlarını desteklemeye daha çok önem vermeleri gerektiğini düşünmektedir. 
Tablo 3. Federasyonlarda Görev Yapan Personelin Hizmet Sürelerine Göre t Testi

\begin{tabular}{|c|c|c|c|c|c|}
\hline Maddeler & Hizmet Süresi & $\bar{x}$ & s & $\mathrm{t}$ & $p$ \\
\hline \multirow{2}{*}{ 1. Sponsor firmalar doğrudan federasyona gelerek anlaşma yapmalıdır. } & $1-10 \mathrm{yıl}$ & 3,36 & 1,48 & \multirow{2}{*}{.757} & \multirow{2}{*}{.451} \\
\hline & 11 yıl ve üstü & 3,17 & 1,30 & & \\
\hline \multirow{2}{*}{$\begin{array}{l}\text { 2. Sponsorluk yapacak kuruluşun kamuoyunda tanınmış olması teklifin } \\
\text { kabulünde etkilidir. }\end{array}$} & $1-10 \mathrm{yll}$ & 3,26 & 1,20 & \multirow{2}{*}{1.03} & \multirow{2}{*}{303} \\
\hline & 11 yıl ve üstü & 3,02 & 1,29 & & \\
\hline \multirow{2}{*}{$\begin{array}{l}\text { 3. Sponsorluk yapacak kuruluşun kamuoyunda olumlu imajının } \\
\text { bulunması teklifin kabulünde etkilidir. }\end{array}$} & $1-10 \mathrm{yıl}$ & 3,56 & 1,13 & \multirow{2}{*}{2.22} & \multirow{2}{*}{$.028^{*}$} \\
\hline & 11 yıl ve üstü & 3,08 & 1,21 & & \\
\hline \multirow{2}{*}{$\begin{array}{l}\text { 4. Sponsorluk yapacak kuruluşun ürünlerinin insan sağlığına yararlı } \\
\text { olması teklifin kabulünde etkilidir. }\end{array}$} & $1-10$ yıl & 3,78 & 1,24 & \multirow{2}{*}{2.06} & \multirow{2}{*}{$.041^{*}$} \\
\hline & 11 yıl ve üstü & 3,33 & 1,19 & & \\
\hline \multirow{2}{*}{ 5. Sponsorluk teklifinin kabul edilmesinde teklifin miktarı etkilidir. } & $1-10 \mathrm{yll}$ & 3,54 & 1,16 & \multirow{2}{*}{1.04} & \multirow{2}{*}{.297} \\
\hline & 11 yıl ve üstü & 3,32 & 1,17 & & \\
\hline \multirow{2}{*}{$\begin{array}{l}\text { 6. Yaygın olmayan spor branşlarında daha az sponsorluk teklifi } \\
\text { yapılmaktadır. }\end{array}$} & $1-10 \mathrm{yıl}$ & 4,16 & 1,05 & \multirow{2}{*}{2.59} & \multirow{2}{*}{$.011^{*}$} \\
\hline & 11 yıl ve üstü & 3,60 & 1,33 & & \\
\hline \multirow{2}{*}{$\begin{array}{l}\text { 7. Takım sporunun ağırlıkta olduğu branşlarda ilgili federasyonlara daha } \\
\text { çok sponsorluk teklifi yapılmaktadır. }\end{array}$} & $1-10 \mathrm{yıl}$ & 3,56 & 1,16 & \multirow{2}{*}{.716} & \multirow{2}{*}{.475} \\
\hline & 11 yıl ve üstü & 3,41 & 1,16 & & \\
\hline \multirow{2}{*}{ 8. Sponsorlar daha çok ulusal spor organizasyonlarını üstlenmelidir. } & $1-10 \mathrm{yıl}$ & 2,63 & 1,21 & \multirow{2}{*}{1.56} & \multirow{2}{*}{.119} \\
\hline & 11 yıl ve üstü & 2,97 & 1,20 & & \\
\hline \multirow{2}{*}{$\begin{array}{l}\text { 9. Sponsorlar daha çok uluslar arası spor organizasyonlarını } \\
\text { üstlenmelidir. }\end{array}$} & $1-10 \mathrm{yll}$ & 2,89 & 1,35 & \multirow{2}{*}{.012} & \multirow{2}{*}{.990} \\
\hline & 11 yıl ve üstü & 2,89 & 1,10 & & \\
\hline \multirow{2}{*}{$\begin{array}{l}\text { 10. Sponsorlar yerel yönetimlere ait spor tesislerinin bakımını, onarımını } \\
\text { ve yapımını üstlenmelidir. }\end{array}$} & $1-10 \mathrm{yll}$ & 2,75 & 1,29 & \multirow{2}{*}{1.29} & \multirow{2}{*}{.196} \\
\hline & 11 yıl ve üstü & 2,46 & 1,20 & & \\
\hline \multirow{2}{*}{$\begin{array}{l}\text { 11. Sponsorlar ulusal ve uluslararası gençlik ve spor organizasyonlarını } \\
\text { üstlenmelidir. }\end{array}$} & $1-10 \mathrm{yll}$ & 3,57 & 1,32 & \multirow{2}{*}{.358} & \multirow{2}{*}{.721} \\
\hline & 11 yıl ve üstü & 3,65 & 1,09 & & \\
\hline 12 Snonsorlar daha cok nakdî ödeme vanma & 1-10 yıl & 3,82 & 1,15 & 268 & $008 *$ \\
\hline 12. sponsonal dana çok hakui odeme yapmanair. & 11 yıl ve üstü & 3,27 & 1,13 & 2.00 & .000 \\
\hline 13 Sponsorlar oku & $1-10 \mathrm{yıl}$ & 3,85 & 1,18 & 130 & 279 \\
\hline & 11 yıl ve üstü & 3,57 & 1,20 & & .219 \\
\hline
\end{tabular}

${ }^{*} p<0.05$

Sponsorlukla ilgili toplam 13 maddede, federasyonlarda görev yapan personelin görevlerine göre görüşleri puanlarının ortalamaları üzerinde yapılan varyans analizi sonucunda, istatistiki olarak anlamlı bir fark bulunmamıştır. Ancak, 6. maddede yer alan "yaygın olmayan spor branşlarında daha az sponsorluk teklifi yapılmaktadır" ifadesine ilişkin, federasyon genel sekreteri $(\bar{x}=4.04)$, uzman $(\bar{x}=4.15)$ ve memurların $(\bar{x}=3.86)$, görüşleri diğer maddelere göre yüksek düzeyde gerçekleşmiştir. 10. maddede yer alan, "sponsorlar yerel yönetimlere ait spor tesislerinin bakımını, onarımını ve yapımını üstlenmelidir" ifadesine ilişkin federasyon genel sekreteri $(\bar{x}=2.76)$, uzman $(\bar{x}=2.73)$ ve memurların $(\bar{x}=2.44)$ görüşleri diğer maddelere göre düşük düzeyde gerçekleşmiştir.

Federasyonlarda görev yapan personelin eğitim düzeylerine göre, toplam 12 maddeye ilişkin görüşleri puanların ortalamaları üzerinde yapılan tek yönlü varyans analizi sonucunda, .05 düzeyinde anlamlı bir fark olmadığı saptanmıştır. Ancak 6. maddede yer alan "yaygın olmayan spor branşlarında daha az sponsorluk teklifi yapılmaktadır" maddesine lise mezunu personel $(\bar{X}=3.38)$, ön lisans-lisans mezunu personel $(\bar{X}=4.10)$ ve lisansüstü mezunu personel $(\bar{x}=4.17)$ düzeyinde katıldığını belirtmişlerdir. Personelin eğitim durumlarına göre görüşleri üzerinde yapılan tek yönlü varyans analizi sonucunda, anlamlı bir fark olduğu saptanmıştır $[F(2,123)=4.16, p<0.05]$. Farklılığı yaratan grubu bulmak için uygulanan LSD testine göre, lise mezunu personel, ön lisans-lisans mezunu personel ve lisansüstü mezunu personelden farklı düşünmektedirler. Lise mezunu personel, ön lisans-lisans ve lisansüstü mezunu personele göre, yaygın olmayan spor branşlarında daha az sponsorluk teklifi yapıldığını düşünmektedir.

\section{TARTIŞMA VE SONUÇ}

Federasyonlarda görev yapan personel, GSGM Sponsorluk Yönetmeliği'ne dayanılarak belirlenen ifadelere orta düzeyde katıldığını belirtmiştir. Federasyon personelinin \%44'ü, yaygın olmayan spor branşlarında daha az sponsorluk teklifi yapıldığını, \%33'i ise sponsorların yerel yönetimlere ait spor tesislerinin bakımını ve onarımını üstlenmesi gerektiğini düşünmektedir. Lise mezunu personel, ön lisans-lisans ve lisansüstü mezunu personele göre, yaygın olmayan spor branşlarında daha az sponsorluk teklifi yapıldığını düşünmektedir. Yaygın olmayan branşlarda da sponsorluk anlaşmaları yapılabilmesi için bu branşları tanıtıcı çalışmalara ağırlık verilebilir.

Kıdemi 10 yıldan az olan personel, daha kıdemli personele göre, sponsor kuruluşun kamuoyundaki imajının olumlu olmasının ve ürünlerinin insan sağlığına yararlı olmasının teklifinin kabul edilmesinde daha çok etkili olduğunu, sponsorların okul sporlarını desteklemeye daha çok önem vermeleri gerektiğini ve yaygın olmayan spor branşlarında daha az sponsorluk teklifi yapıldığını düşünmektedir. 
Sponsorluk yönetmeliğinin tam anlamıyla uygulanabilmesi için, federasyon personelinin yönetmeliğin uygulanması konusunda hizmetiçi eğitimden geçirilmesi yararlı olacağı düşünülmektedir. Federasyon personelinin spor konusunda hizmetiçi eğitimden geçirilmesi sponsorluk anlaşmaları yoluyla elde edilecek gelirleri artıracaktır.

\section{KAYNAKÇA}

1. Argan, M., Spor sponsorluğu Yönetimi. Detay yayıncılık. Ankara, 2004.

2. Anonim., Büyük Larousse Sözlük ve Ansiklopedisi, Cilt: 21. Milliyet Gazetecilik, 1997.

3. Anonim., Resimli Redhouse, İngilizce-Türkçe Sözlük. Milliyet Yayınları, 1991.

4. Beech, J., Chadwick, S., The Busines Of Sport Managament. Person Education Limited, England, 2004.

5. Yaral, Ç., Z., İşletmelerde Sponsorluk Çalışmaları İçinde Sporun Yeri, Marmara Üniversitesi Sosyal Bilimler Enstitüsü Yüksek Lisans Tezi, İstanbul, 1998.

6. Okay, A., Halkla İlişkiler Aracı Olarak Sponsorluk, Epsilon Yayıncılık, İstanbul, 1998.

7. Balcı, V., Spor Pazarlaması Kavramlar Yöntemler Örnekler, Bağırgan Yayınevi, Ankara, 2005.

8. Parks, J., B., B., Zanger, R., K., Quarterman, J., Contemporary Sport Managament, Human Kinetics, USA, 1998.

9. Argan, M., Katırcı, H., Spor Pazarlaması, Nobel Yayın Dağııı. Ankara, 2002.

10. Anonim., Özerk Olan Futbol Federasyonun Yıllık Geliri, Cumhuriyet Gazetesi, 23 Haziran 2006.

11. Ekenci,G.,İmamaoğlu, A., F., Spor İşletmeciliği. Nobel Yayınevi, Ankara, 2002.

12. Erturan, E. E., Yenel F., "Federasyon Başkanlarının Spor Federasyonlarının Özerkliğine İlişkin Görüşlerinin Değerlendirilmesi”. Gazi Beden Eğitimi ve Spor Bilimleri Dergisi. IX (2004), 1: 71-87, 2004.

13. Anonim., Resmi Gazete Sayı: 25494, Gençlik ve Spor Genel Müdürlüğü Sponsorluk Yönetmeliği. 16.06.2004.

14. http://www.sponsorluk.gov.tr/imagines/istatistik / 3.html (19.07.2007).

15. Ural, A., Kılıç, İ., Bilimsel Araştırma Süreci ve SPSS ile Veri Analizi. Detay Yayıncılık. Ankara, 2006.

16. Tavşancıl, E., Tutumların Ölçülmesi ve SPSS ile Analizi. Nobel Yayın Dağıtım. Ankara, 2006.

17. Sipahi, B., Yurtkoru, E., S., Çinko, M., Sosyal Bilimlerde SPSS ile Veri Analizi. Beta Yayınları. İstanbul, 2007.

18. Büyüköztürk, Ş., Sosyal Bilimler İçin Veri Analizi Elkitabı, Pegem A Yayıncılık. Ankara, 2002. 